\title{
SUN AND LIGHT, OR ON THE AGENT INTELLECT
}

\author{
Sol y luz, o sobre el intelecto agente \\ Hernán Martínez Millán \\ Duquesne University
}

\begin{abstract}
This paper examines some passages in the Treatise on Human Nature in which Thomas Aquinas, following Themistius, refers to Plato's analogies between the sun and the soul in order to prove that the agent intellect is something that belongs to the soul. It also analyzes the analogy between the light and the soul that Aquinas mentions, which is taken from Aristotle. The main task at hand will be to revisit the question of how Aquinas interprets Plato and Aristotle in this particular section of the Treatise on Human Nature.
\end{abstract}

Key words: agent intellect, soul, sun, light, Aquinas, Plato, Aristotle.

\section{RESUMEN}

Este artículo examina algunos pasajes del Tratado sobre la naturaleza humana en donde Tomás de Aquino, siguiendo a Temistio, se refiere a las analogías entre el sol y el alma para demostrar que el intelecto agente es algo que pertenece al alma. También analiza la analogía entre la luz y el alma que Aquino menciona, la cual es tomada de Aristóteles. La tarea principal será revisitar la cuestión de cómo Aquino interpreta a Platón y Aristóteles en esta sección del Tratado sobre la naturaleza humana.

Palabras clave: intelecto agente, alma, sol, luz, Aquino, Platón, Aristóteles.

The reason why Aristotle came to postulate an agent intellect was his rejection of Plato's theory that the essences of sensible things existed apart from matter, in a state of actual intelligibility.

Thomas Aquinas

Without doubt Thomas Aquinas has been one of the most influential thinkers in western philosophy. His contemporary hermeneutics not only depends on the canonical place that he has held in Catholic philosophy as a Doctor Communis since 1880, but also because in many ways contemporary philosophers ${ }^{1}$ have considered that his philosophy is a medieval variation of Platonic thought. Keeping in mind these two extreme claims about Aquinas's philosophy (as a canonical Catholic thinker or as a Platonic thinker whose ideas we necessarily have to "invert," in Nietzsche's term), in this paper I would like to examine some places in the Treatise on Human Nature in which Aquinas puts together pieces of Plato's and Aristotle's philosophies in order to demonstrate his point of view. Basically, I will take into account question 79,

1 See F. Nietzsche, Twilight of the Idols, p. 171. R. Rorty, Consequences of Pragmatism, p. 100. 
article 4 of the Treatise on Human Nature in which Aquinas, following Themistius, refers to Plato's analogies between the sun and the soul in order to prove that the active intellect is something that belongs to the soul. I will also consider the other analogy between the light and the soul that Aquinas mentions, which is taken from Aristotle. The main task at hand will be to revisit the question of how Aquinas interprets Plato and Aristotle in this particular section of the Treatise on Human Nature.

In order to achieve this main objective, I will develop the following framework. First, I would like to explain what the principal goal of Aquinas is in article 4 of question 79. Then I will study each of the analogies that Aquinas makes there and will also say something about the context in which each comparison appears in Plato and Aristotle. Immediately afterward I will claim that the comparisons in Aquinas acquire a new meaning, which reinforces Aquinas's essential claim about the necessity of a higher intellect, thanks to which everything exists and is understandable. In other words, I am interested in the analogies that make Aquinas want to subordinate the power of intellect to an unchangeable and perfect higher intellect. Finally, I will suggest that Aquinas's use of these analogies lets him affirm his existential point of view (in the Thomist sense of "existential") that God is the primary existent from which the human soul receives the power of understanding by illuminating the phantasms.

\section{WHY THE INTELLECT DOES NOT BELONG TO THE SOUL}

I would first like to consider what Aquinas's main objective is in article 4 of question 79. As is well known, Aquinas not only takes into account the philosophical problem of "whether there is one separately existing agent intellect for all men." This question was studied by Aquinas in the following places: Summa Contra Gentiles (SCG) 2.76 and 78, On Spiritual Creatures (DQSC) a. 10, Commentary on De anima 3 lesson 10, and Disputed Questions de Anima (DQA) a. 5. Basically, Aquinas wanted to resolve a hermeneutic problem provoked by Aristotle's De Anima, which has theological implications. It is notable that Aquinas's references to Aristotle about this problem were taken from De Anima 3. In these references, Aquinas presents many objections to the way in which Aristotle affirmed that the agent intellect could exist separate from the soul. Summarizing these arguments, the central points are:

First, an active intellect is always engaged in intellective understanding, which proves that humans are not capable of doing this since intellective understanding in humans is periodical. This comment can also be seen in Summa Contra Gentiles (chapter 76, 3), where Aquinas says: "the agent intellect is not in a state of potentiality." See also DQSC art. 10, where Aquinas says: "there is nothing in our soul which always understands."

Second, the active intellect is a substantival being in actuality; that is to say, it cannot be in act and potentiality at the same time. Or, as Aquinas says in Questiones Disputate De Anima (QDA), "the agent intellect is not at one time knowing and at another not" (art. 5.)

Third, the intellectual agent has properties that belong to separate substances, such as that it is incorruptible, separate and perpetual. The same comment can be seen in QDA art. 5.4, in which Aquinas affirms: "The philosopher attributed to the agent intellect certain properties which belong only to separate substances."

Fourth, the intellect does not depend on bodily dispositions since this is not likened to the body (and the same comment appears in QDA art. 5.5). This can also be seen in CAA, where he affirms (742) that Aristotle argues: "only the mind separated from the matter is that which is really mind . . the whole intellect is so described because it operates without a bodily organ." 
Fifth, the active intellect is illuminated by something higher than the soul from which the intellect takes its illumination, as John says in 1:9 (the same comment is in DQSC art. 10.1. and QDA art. 5.6). The main argument here is that man, "[i]n order to learn . . . requires instruction, which is given by a teacher," who is God.

Sixth, the agent intellect is like an art whose principles are separate from the objects. This is also stated in QDA art. 5.8: "But an art is a principle separate from the objects produced by it. Therefore the agent is also a separate principle." Also see CAA 10, 735-739.

Seventh, as works of art and nature resemble the agent that produces them, the active intellect should also be similar to the soul but, as we know, the soul is not as perfect and as happy as the agent intellect. Also see QDA art. 5.9.

These are some arguments from Aristotle's De Anima that Aquinas presents to us in order to indicate a "possible way" that some authors took in order to argue that the active intellect is not something that belongs to the soul. So Aquinas's main objective will consist in shedding light on this incorrect interpretation of the Stagirite, since he considers that the agent intellect, as a possible intellect, belongs to the human soul.

Before moving on to how Aquinas resolves this philosophical issue, which has theological implications (the most important being that according to Christian tradition the human soul participates in a certain sense in divine illumination), I would like to offer a general interpretation of these seven objections (though perhaps there could be more). I would like to note that all of these objections are plausible since, as we know, Aristotle insists on the following crucial characteristics of his theory of knowledge:

First, in order to overcome Plato's Theory of Forms, Aristotle has to emphasize in many different ways the possibility that living things can be the objects of knowledge despite the fact that they are movable and perishable. Since Plato underscored the necessity of postulating an intelligible world that is imitated on "sublunar" things, Aristotle, who wanted to satisfy his hope to apprehend living things, had to affirm that not only actual things could be known, but also those things that are not yet completely developed. From this consideration, one can follow why some interpreters, following the same train of thought, had doubts about the possibility that the human mind is always engaged in intellective understanding, which is the main concern. Also, why some had doubts about whether the human soul could be in act and potentiality at the same time, which is contrary to the non-contradiction principle. ${ }^{2}$

Second, if there are things whose main attribute is being in act or being in potentiality, for example, God for the first case and man for the second case, Aristotle was very careful to consider the precise attribute of each of these entities, and also to establish borders for each of the sciences that studies these kinds of subjects. For Aristotle each subject, viz. god, agent intellect, and possible intellect, has very specific qualities. One could consider that the third claim (in the order that I presented them before) is linked to the nature of knowing objects and their respective areas of knowledge.

Third, the next objection is also plausible, since one could imagine that, contrary to Plato's essentialist account of the process of knowledge, Aristotle, who creates an alternative account to Parmenides's "well-rounded ball,"3 would consider that the intellect depends on bodily dispositions. Further, his accounts about sensorial organs in De Anima reinforce this

2 "It is impossible for the same thing to belong and not to belong at the same time to the same thing and in the same respect." See Metaph IV 3 1005b19-20.

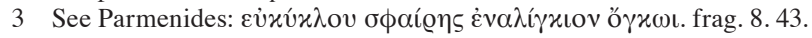


procedure, since, as we know, according to Aristotle the rational soul is: $\delta$ ı̀ $\dot{\eta} \psi v \chi \dot{\eta} \dot{\varepsilon} \sigma \tau \iota v$

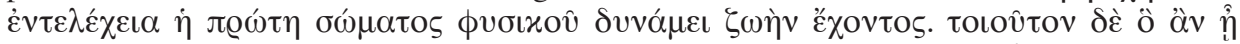

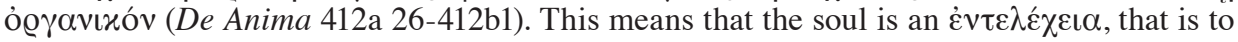
say, "the first being-fully-itself," in Shiffman's translation, so the soul is not a body but something that lets bodies be an "it," that is to say, to be fully-itself as an "it." Aristotle's predecessors did not consider that the soul is not a body since in that case it would have to be composed of matter. Matter is not in virtue of itself because matter is incapable of determining itself; that is to say, it does not let us explain how natural bodies are organized. Living beings do not live without specific matter.

Finally, I would like to say that the 5th, 6th and 7th objections in my list above reinforce the idea that something that is in actuality might be the cause of learning, production and virtue. All these qualities are different from human intellect, which is capable of them by virtue of something else, that is to say, the agent intellect.

So, as I said previously, all of these interpretations are "possible" to deduce from Aristotle's philosophy, but they are not correct, in Aquinas's terms. Aquinas, who had as his main purpose to understand the Christian God revealed in the Old Testament as a font of

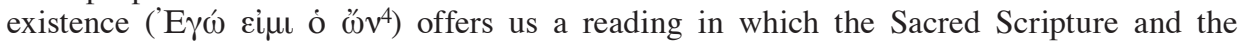
Philosopher could coexist, avoiding having to consider that the agent intellect does not belong to our soul. On the contrary, Aristotle's philosophy negates a fundamental biblical principal that holds Jesus "was the true light, which enlightens every man who comes into the world" (q. 79, a. 4.), as Thomas quotes when he refutes this idea. Aquinas certainly keeps in mind what Saint Paul claims about the arrogance of philosophers who dare to explore God's mind: "For who has known the mind of the Lord so as to instruct him?" (I Corinthians 2:16).

\section{PLATO'S ANALOGY OF THE SUN AND ARISTOTLE'S ANALOGY OF THE LIGHT}

\section{a. Plato's Analogy of the Sun}

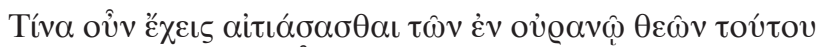

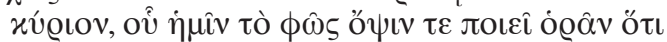

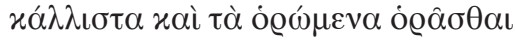

Plato, Republic

As I proposed at the beginning of this essay, in this section I would like to consider how these analogies appear in Plato and Aristotle. The first analogy that I will analyze is the sun analogy. As is well known, Plato makes this analogy in the Republic VI 507d. The Socrates of this book expects to offer to Glaucon a description of the "child of the good" ( $\alpha \gamma \alpha \theta$ ov

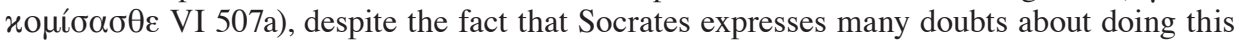
since he does not pretend intentionally to "defraud [Glaucon] in some way" (VI 507a). As we know, in spite of this advice, Socrates will finish his discourse with the words: "Glaucon

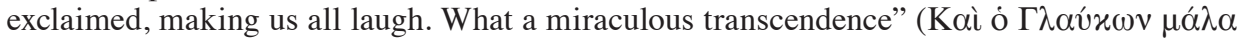

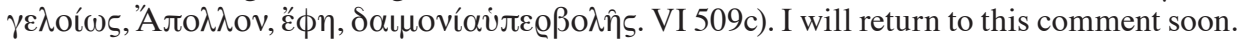

4 Exodus 3, 14. "I AM WHO I AM." See The New Oxford Annotated Bible, ed. Michael Coogan. Oxford: Oxford UP 2001. 
The analogy that Socrates makes to the sun basically consists of proving that there is a "third thing" that is very important to the process of perceiving sounds and colors because it lets the senses grasp them. The faculty of sight and the thing that is seen need a third medium or thing to help the faculty develop its function, and in turn something that it is possible to see requires the intervention of a third thing so that the faculty of seeing can grasp its physical appearances. The light is this third thing that lets the eye, which has the faculty of seeing, see the things of the sensible world. But really this is thanks to the sun, which is "the agent responsible for this" (VI 508a). The sun causes light but the sun is not the light (VI 508b). That is to say, according to Socrates, "the good stands in just the same relation to thinking and the things which can be thought as the sun, in the world of sight, stands to seeing and the things which can be seen" (ö

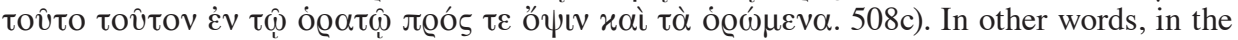
world of thought a similar process is taking place to what happens in the world of perception. The good sheds light on the intelligible things that are the object of thought. Also, light illuminates the sensible things so that the eye can see.

As I said previously, Glaucon made fun of Socrates, for which reason Socrates had to find another way of explanation. The other way is known as the simile of the line. Using mathematical terms, Socrates tries to reveal the Theory of Ideas to Glaucon. One could affirm that similarly the Parable of the Cave (VII 541a) is the ultimate pedagogical tool to explain this theory to Glaucon, which for him seems a sort of miraculous transcendence. ${ }^{5}$

\section{b. Aristotle's Analogies of the Light}

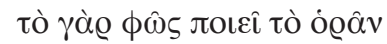
Aristotle, Sense and Sensibilia

Despite the fact that in the q. 79, a. 4, which is the question that we are examining, Aquinas does mention the exact reference in which he compares the active intellect and light, there are other places in Aquinas's works in which he quotes Aristotle, for example CAD 72831. The reference to Aristotle's comparison with light is in De Anima III 5 430a 14-17:

And in fact thought, as we have described, is what it is by virtue of becoming all things, while there is another which is what it is by virtue of making all things: this is a sort of positive state like light; for in a sense light makes potential colors into actual colors.

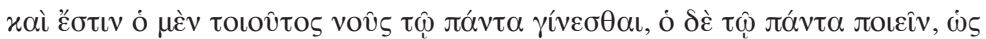

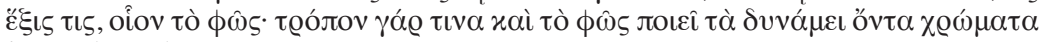

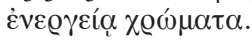

As Polansky clarifies in his commentary on this passage, "Light or the illuminated transparent is the medium for vision, and what is the agent in thought serves as a kind of medium so that the intelligible objects get the mind thinking" (463). According to Polansky, Aristotle "borrows the comparison to the light in 430a15, as commentators observe, from the Sun-God analogy in Plato's Republic vi 506d ff." So the source of this comparison is

5 Glaucon's judgment of the Theory of Ideas is reminiscent of Aristotle's opinion about the same subject in Metaphysics I 9 992a 25 ff.: "but while we fancy we are stating the substance of perceiving things, we assert the existence of a second class of substance, while our account of the way in which they are the substances of perceiving things is empty talk; for sharing, as we said before, means nothing." 
Plato, whom Aquinas also has to refute, as I noted in the epigraph of this paper, since Aquinas's theory of the soul does not let him hold a radical separation between the sensible world and the intelligible world, as Plato does. Aquinas, like Aristotle before him, emphasizes the possibility of finding an intermediate link between the human soul and the higher intellect, thus avoiding Plato's dualism.

On this matter, I would like to note that for Aristotle the activity of sense perception is

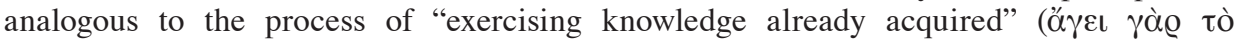

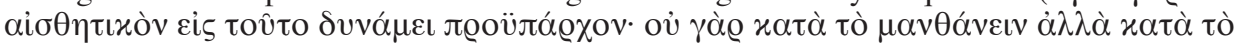

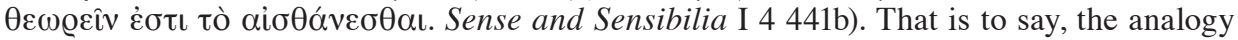
that Aristotle makes between perceiving and thinking does not describe the process of acquiring knowledge; instead, this analogy suggests the way in which human beings put into action the knowledge that they have actually acquired before. In this way it is possible to sustain this analogy, since according to Aquinas "there is no parallel between the sensory power and the intellect" (q. 84, a. 4).

\section{THE ANALOGY OF LIGHT AND SUN IN AQUINAS Q.79.A.4}

Hence, one must claim that within the human soul there is a power, derived from a higher intellect

(derivata a superiori intellectu)

Aquinas, Treatise on Human Nature

Let me first consider Aquinas's brief reference to Aristotle's analogy of light. As we know, Aquinas has the goal in this section of eliminating doubts about whether the active intellect belongs to the human soul. Aquinas categorically affirms: "the active intellect of which the philosopher speaks is something that belongs to the soul." So his efforts in this section are addressed to demonstrating that pagan philosophy and Christian revelation hold one and the same thing, but he is careful to make clear that "the human soul participates in a certain particular power" of the true light (q. 76. a. 4. reply to objection 1), which as John says in 1:9 illuminates everything as a universal cause.

According to Aquinas, "Aristotle compared the active intellect to light, which is something received in the air" (q. 79, a. 4). He also affirms the same opinion in CAD 728-31: "There is that intellect, which is such as being able to become everything; and there is that which acts upon everything, as a sort of state, like light; for light too, in a way, makes potential colors actual." This can also be seen in DQSC art. 10, where Aquinas affirms: "And it seems clear that Aristotle realized this when he said [III De An., 5, 430a 13] that "there must be these differences in the soul,' namely, the agent and the possible intellects." He also says [430a 15] that the agent intellect is, as it were, a brightness, which is a participated light.

Thus the following considerations should be clear. First, there is a relationship among the agent intellect, the intelligible objects (of which it is composed) and the human rational soul. Because the agent intellect sheds light on the intelligible objects, the human rational soul can grasp the essence of things. This is possible through a mental process called abstraction: "We know this from experience when we perceive ourselves abstracting universal forms from particular conditions" (q. 79, a. 4). Second, light, or better the sun, which provides light, has a separate existence from the things that it illuminates. This is a very important detail because if, for any reason whatsoever, we consider that light and things are the same, since God and creatures are related but not the same, so creatures are in procession to God. That is to say, as Aquinas affirms, "in addition to the universal agent causes, proper powers ... are derived 
from the universal agents and given to individual perfect things" (q. 79, a. 4.). As light makes sensible things visible to the faculty of perceiving, so the agent intellect makes intelligible to the rational soul what is composed of matter and form. In the most general order of causes (e. g. in the universe) one could sustain that God plays this role, "but as 'sublunar things" " have immediate causes, which of course derive from the universal cause, so the rational soul grasps these causes.

The main claim by Aquinas is that in the soul "there is power, derived from a higher intellect, through which it can illuminate the phantasm," that is, the image that impresses itself on our senses. This power is in the human soul since the rational soul as a rational entity is capable of intellective cognition.

Once again, Aquinas compares light to the active intellect; he also establishes the same comparison with Plato's analogy of the sun since, according to him, Plato "compared the separated intellect impressed on our souls to the sun" (q. 79, a. 4). From my point of view, this analogy is more relevant here than Aristotle's comparison to the sun because the main point that Aquinas wants to argue is that there clearly is a "universal agent"; furthermore, in the case of the "natural entities" we refer to a "proper power." These, despite the fact that they are "derived from the universal agent," are not the immediate causes of natural entities. That is to say, Aquinas once again emphasizes the conception about creatures being in procession to God since He is the first cause (in the order of the "ratio") and the last principle (in the order of temporal events). Such a conception is not in conflict with the idea that natural entities have immediate causes. According to Aquinas, following Plato's analogy of the sun, the sun is a "remote" cause of man (if I may use the expression) or, as Aquinas says, the sun alone does not generate man, for "there is in man a power to generate man." That is to say, although Plato postulates the sun as a final cause of natural things, ${ }^{6}$ he does not believe that such an ultimate cause can directly explain the events that take place in the sensible world. Following the same train of thought, Aquinas considers that the rational soul has the power to understand things, but this power comes from the higher intellect.

So the analogy of the sun not only has the purpose of illustrating the Aristotelian contribution about light as a third medium, but it also allows Aquinas to point out the differentiation between the universal cause and the natural entities. This distinction is not only important to understanding how the human mind through abstraction can grasp the essences of entities, but also helps trace the borders that separate first philosophy, physics, practical philosophy and productive philosophy. On the contrary, if we do not indicate that proper causes explain the nature of natural entities, we might consider everything as the object of theology rather than as the object of natural sciences or other areas of knowledge.

Finally, I would like to stress the existential level of these analogies in Aquinas's response in this section of the Treatise on Human Nature. As we know, Aquinas was very concerned about the possibility of having knowledge of the sensible world, while at the same time he wanted to construct a Christian theology that would allow him to understand the nature of God, to the extent that this is possible for the human intellect. As Aquinas notes in De Anima, Aristotle wanted to overcome the negative effects of Platonic philosophy, which had reduced sensible things to nothing more than shadows, objects of opinion but not of knowledge. According to Aquinas this was possible because Plato had separated two essential attributes of things, namely matter and form. Aristotle, according to Aquinas, had postulated the agent

6 See Plato Republic VI 508b: "The sun gives to what is seen, I think you would say, not only its ability to be seen, but also birth, growth and sustenance-though it is itself birth or generation." 
intellect in order to save the sensible word from the unknowable. This philosophical fashion triggered a serious problem since for some thinkers (such as Avicenna ${ }^{7}$ ), Aristotle had considered a kind of intellect that could exist separately from the human soul. Aquinas sheds light on this confusion by saying that the agent intellect operates like the sun or light in the sensible world. As the sun causes light, so God causes everything that is in the "sublunar world." This does not mean, however, that there are "proximate causes" that help us understand the nature of things, since as Aquinas says in q. 84, a. 4: "But it is not led into actuality by any separated intellect as a proximate cause - though perhaps as a remote cause."

In this order of ideas, the analogies examined in this paper play a crucial role in Aquinas's philosophy since, just as God is the existent in itself, so creatures are proximate causes that the agent intellect can discern without a need to recur to God. Aquinas's existential point of view asserts that the God of the Christian tradition, like the sun in Platonic terms, is a remote cause; even as it allows him to identify the first cause of the universe, it also allows us to understand the levels of causes that generate "sublunar things." Like God, who is the existent Himself who has created everything that is (and thanks to whom creatures are intelligible), but who does not have a direct cause, so also the sun (in Platonic pagan philosophy), the creator of the sensible world, makes visible all things that the human being can see.

Hernán Martínez Millán opsomanes@gmail.com

Recibido: 12 de febrero de 2013

Aceptado: 4 de abril de 2013

\section{BIBLIOGRAPHY}

Aristotle. The Complete Works of Aristotle. Ed. Jonathan Barnes. Princeton: Princeton University Press, 1984.

- De Anima. Ed. Mark Shiffman. Villanova, PA: Villanova University Press, 2011.

Coogan, Michael, ed. The New Oxford Annotated Bible. Oxford: Oxford University Press, 2001.

NiETzsche, Friedrich. The Anti-Christ, Ecce Homo, Twilight of the Idols, and Other Writings. Cambridge: Cambridge University Press, 2005.

Plato, The Republic. Ed. G. R. F. Ferrari. Cambridge: Cambridge University Press, 2000.

Polansky, Ronald. Aristotle's De Anima, Cambridge University Press, 2008.

RorTy, Richard. Consequences of Pragmatism. Minneapolis: University of Minnesota Press, 1982.

Thomas Aquinas. Treatise on Human Nature. Ed. Alfred J. Freddoso. South Bend: St. Augustine's Press, 2010.

- Questiones Disputatae de Anima. Ed. Raymund M. Spiazzi. London: Herbert Book, 1949.

- Summa Contra Gentiles. Ed. Anton C. Pegis. Notre Dame, IN: University of Notre Dame Press, 1975.

- Disputed Questions On Spiritual Creatures. Ed. Mary C. Fitzpatrick and John J. Wellmuth. Milwaukee: Marquette University Press, 1949.

- Commentary on Aristotle's De Anima. Ed. Robert Pasnau. New Haven: Yale University Press, 1951.

7 See q. 84, a. 5 of Treatise on Human Nature. 